\title{
Alfonz XIII - the possibilities and constraints of a neutral monarch ${ }^{1}$
}

\section{Mária Pallagi}

The political ars poetica of Alfonz XIII played an important role in the history of Spain between 1914-18. Despite this, there have been only few bibliographies which can meet professional demands on his personality. Most of the literature refers to the works of Charles Petrie ${ }^{2}$ and Robert Sencourt ${ }^{3}$. Their publications are especially valuable as the authors - as contemporaries - had the opportunity to consult personally with the people around Alfonz. Considering these, the files of the Zeitungsarchiv collection in the Viennese imperial archives (HHStA) gain special importance as - together with some other fonds of the HHStA about Spain in World War I - provide the possibility to reconstruct the policy of King Alfonz during World War I within a mini-biography.

The principles which determined the aims of King Alfonz in the examined period are well-reflected by the statement of the Spanish monarch at the meeting with Winston Churchill in Madrid in 1914.

During their conversation King Alfonz once said that if military conflict happened, he would consider three arguments: to keep Spain out of the conflict, to do his best so that the foreign trade of the country would not suffer from the conflict and to help everyone who is in need as a result of the situation. ${ }^{4}$

In our essay we wish to explore how the documents of HHStA justify that the activities of King Alfonz in the above mentioned three fields were realized.

It is indisputable that due to King Alfonz's efforts Spain remained neutral throughout the war. However, we have to draw attetion to the fact that it was neutrality only in the political sense as making use of the geostrategic position of the country - he tried to make profit off the trends of the war market. $^{5}$

The declaration of neutrality took place surprisingly early on 30th July, although without the assent of the cortes. The Spanish parliament first gathered after the beginning of the war only at the beginning of November, so the declaration of neutrality could not have been ratified by the two chambers earlier. Congress confirmed the declaration on 5 November and the senate ratified neutrality three days later. ${ }^{6}$ With the ratification a sometimes fierce and showy struggle between political forces began. It lasted for four and a half years and during this period of time it was the King's responsibility to maintain balance among political forces. ${ }^{7}$

\footnotetext{
${ }^{1}$ Our research in Vienna was supported by the CH Scholarship of the Hungarian Scholarship Committee, the Austrian Bundesministerium für Wissenschaft und Verkehr and the Austro-Hungarian Action Fund, for which we express our acknowledgement herein.

Our essay is part of a greater research, in which we examine Spanish neutrality during World War I according to the reports of the ambassador of the AHM to Madrid. The antecedents, process of research and the availability of the presented documents are published in detail in the introduction of our essay titled 'The First World War and the Spanish Neutrality' Jatepress, Szeged, 2003.

${ }^{2}$ Charles PETRIE: King Alfonso XIII and his Age. Chapman \& Hall LTD, London, 1963.

${ }^{3}$ Robert SENCOURT: King Alfonso. Faber and Faber Limited, London, 1942. Both Petrie and Sencourt often refer to the writing of Princess Pilar, the cousin of the King: Bavaria, Princess Pilar of/ Chapman-Huston, Major Desmond: Don Alfonso XIII. A Study of Monarchy, London, 1931., also referred to in Henry VALLOTTON, Alfons XIII., Lausanne, 1943., also in Spanish Alfonso XIII. Rey de España: „, Mi reinado ante la Historia”. in: „A.B.C.”, Madrid, 27. Febr. 1960, Antonio CALERO: „El papel político de la Corona en el reinado de Alfonso XIII: criterios para una revisión”. In España 1898-1936. Estructuras y cambio. Madrid, 1984., Julian CORTES CAVANILLAS: Alfonso XIII. Barcelona, 1966., Melchor Fernandez-Almagro: Historia del reinado de Alfonso XIII. Barcelona, 1966., Victor ESPINÓS MOLTO: Alfonso XIII y la guerra. Espejo de neutrales. Madrid, 1918.

${ }^{4}$ The First World War and Spanish Neutrality... quoted above p. 11

${ }^{5} \mathrm{Cp}$ : The First World War and ... quoted above pp. 6-8.

${ }^{6}$ Ibid.: pp.11-12.

${ }^{7}$ A typical example of the struggle between the Liberal and Conservative forces is the Sept.1914 article of Count Romanones, the leader of the Liberal forces, and the speech of his political opponent, Vásquez de Mella, who is the head of the Charlist forces. Cp.: The First World War...ibid. pp. 25-31. Count Dzieduszycki, the military
} 
The reports of Prince Fürstenberg, the ambassador of the Austro-Hungarian Monarchy to Madrid, contimue to inform us about the always changing political balance between the Germanophil and proAllied forces. ${ }^{8}$

On the noght before the beginning of the war King Alfonz tried to make closer contact with the Entente. In May 1913, he visited France for the third time to meet President Poincaré, and in the autumn of that same year the French Prime Minister, Barthou, visited Spain in return. It was obvious that these mutual visits - directly or indirectly - were in close connection with the plan of Spain joining the Triple Entente. ${ }^{9}$ In the meantime - and this was quite important for King Alfonz - the primary success of the King's visit to France is that the prejudice, which seemed to be spreading against Spain and the Spanish King, seemed to come to an end. Furthermore, Spain managed to overcome the isolation and returned into the main stream of politics, which also meant that Spain became a monarchy again that had to be noted. ${ }^{10}$

The Spanish newspapers also reported the Paris trip of Alfonz in great detail. For example, La Época emphasised in its evaluation 'the conservatives are quite unsatisfied with the present situation. They are truly worried that a closer treaty might be realised between the two countries, which they will try to counteract by all possible means. ${ }^{11}$

The tone of the liberal papaers are completely different. They welcome the Paris trip of Alfonz and consider it the beginning of the economic prosperity of Spain. They express their hope that at least one trade agreement favourable for Spain might be made. They would not be against a political treaty between the two countries on the condition that trade agreements should definitely precede it. ${ }^{12}$

The Liberal, goes even further; they consider the new directions of negotiations the beginning of a new era for Spain. ${ }^{13}$

The Pester Lloyd refers to the importance of the collective interest developing in Marocco, and also to the presence of French and English capital in Spain. 'This means that Spain is getting into the main stream of the French-English Entente,' says the author. He also emphasises that the treaty with Spain would create a possiblity for France to achieve the security of avoiding a two-front war. ${ }^{14}$

The first signs of the new feature of the Spanish foreign policy were reported by Count Wydenbruck, the ambassador of k.u.k. Monarchy on 23 August, 1912, when he refered to the fact that both the press and the public opinion had been on Germay's side before. This was especially important because of the Marocco conflict, and the government also tried to make closer relationships with Germany. 'Now the goverment seems to be changing their policy - says the ambassador - and the Spanish government is trying to make approaches to France. ${ }^{15}$

With respect to this, the 12 September, 1912 report of Count Wydenbruck is especially important. In this repot the Count says, 'England made it clear here, two months ago, that Spain would get free scope against Portugal. ${ }^{16}$

attaché of the k.u.k. Monarchy in Madrid, reported the events as follows: 'At the beginning of the war I sent a telegraph saying that Spain is determined to be neutral in the war. In the chamber meeting today this has been confirmed....

As I myself attended the meeting, I could witness that not only the members of the house, but also the majority of the people present were fairly satisfied with the results..

The successful negotiations, which attached some important questions in connection with the future of Spain, were mainly due to the tactful influence of the King.” ÖStA Kriegsarchiv, Präs. 47-12/10, Akten des Kriegsministeriums, Militärattaché Madrid, Nov. 25.1914. No. 161.

${ }^{8}$ Cp.: The First World War ... quoted above pp. 23. 25. 29. 31.

${ }^{9} \mathrm{Cp}$ : The first world ... quoted pp.15-23. the report of Count Wydenbruck, the ambassador of the AHM to Madrid. 6. May 1913 No.17. HHStA P.A. XX 66. Berichte Spanien 1913.

${ }^{10} \mathrm{Cp}$ : The first world ... quoted pp .18. the report of Wydenbruck. 14. May 1913. No.19. quoted above

${ }^{11}$ HHStA Zeitungsarchiv - hereinafter Z.A. - 180, Spanien, König Alfons XIII. La Epoca, 5.May1913. „Die

Pariser Reise des Königs von Spanien".

${ }^{12}$ The article in the Impercial, quoted above.

${ }^{13}$ Quoted above

14 the article of the Pester Lloyd 9. May 1913. „Der Besuch des Königs Alfonso in Paris”. Quoed above.

${ }^{15}$ HHStA P. A. XX 66. Berichte Spanien 1912. No. 4613.

${ }^{16}$ HHStA P. A. XX 66. Berichte Spanien 1912. No. 49. 
As one of the aims of Alfonz during the war was to unite teh Iberian Penninsula under his reign, ${ }^{17}$ this information might have proved to be dangerous for the Central Powers.

It is interesting that in essays on history the fact that Alfonz and his wife made a visit on Vienna in November 1913 was stated. They say - as for example the Neue Freie Presse reported - 'it did not have any political importance, as Alfonz - being an enthusiastic sportsman - only went to hunt in Selowitz. ${ }^{, 18}$

At this point it is worth noting that the Spanish king had family relations with the AustrianHabsburgs - through his mother Marie Christine -, and his wife, Ena, who was of English origin. ${ }^{19}$ Thus, Alfonz could feel the political debates which became a characteristic feature of Spanish political life within his family. ${ }^{20}$

The dynastic bonds were emphasized by Alfonz in an interview on 24 September 1913, to the New York Herald in the Miramar Castle in San Sebastian 'During the past 11 years, since I was the monarch, I have always made clear which side I am in favour of. I have never forgotten that Bourbon is a French name. In the difficult situation, which developed in Marocco, it is essential that the two countries co-operate closely and France and Spain have to support each other, in the future, hand in hand". ${ }^{21}$

On the other hand, German press attached greater importance to the visit of Alfonz in Vienna.

The Tägliche Rundschau on 25 November reported the King's stay in Vienna as 'a sign that the French-Spanish Entente is not against the Austro-Hungarian Monarchy and its allies. However, Vienna took the opportunity to clarify the power relations in the Mediterranian. ...' The author of the article also says that France might judge the relations of Spain and Austria-Hungary with jealousy, which might lead to similar steps of France towards the Monarchy. The visit of Poincare in Vienna was spoken about, however, it was contradicted there. ${ }^{22}$

The maintenance of Spanish neutrality during the war was not in real danger; however, there were some periods such as the spring of 1917, when - as a concomitant symptom of the economic crisis joining the Entente nearly took place, mainly as a consequence of the policy of the Prime Minsiter Romanones, which was considered to be 'enfant terrible' by the Central Powers.

Salvador de Madariaga also emphasised the role of Alfonz in the policy which resulted in Spain, despite its unfavourable geopolitical position, could stay outside the military conflict, maintaining the balance between the germanophil and aliadophil parties which divided the Spanish political life. ${ }^{23}$

Another report of 26th June, 1916, in connection with neutrality is especially important as it is related to Hungarian affairs. King Alfonz gave an interview to Dr. Révész Andor, the correspondance reporter EST in Madrid. In the interview, the king reinforced Spain's desire for neutrality at whatever cost, even though it might be difficult for the country at times. 'One or the other of the fighting parties sometimes doubts that neutral countries, and among them Spain, will stick to neutrality. However, I have never doubted the position Spain should hold. I hope Spain will be the connecting link between the countries fighting at the moment. We are on friendly terms with Austia-Hungary, and as far as I am concerned I will do everything I can for the Austro-Hungarian prisoners of war so that we can get closer to peace. ${ }^{24}$

\footnotetext{
${ }^{17} \mathrm{Cp}$ : the report of Prince Fürstenberg on 6. July 1914. HHStA P. A. XX 66 Berichte Spanien 1914. Z 17/P.B

${ }^{18}$ HHStA Zeitungsarchiv 180. Spanien. The article of Deutsches Volksblatt on 8. October 1913: „Zum Besuche des spanischen Königspaares in Wien", ill. a Neue Freie Presse, also the articles in Fremdenblatt on 23

November,: „König Alfonso in Wien”

${ }^{19}$ She was the cousin of George V, the King of England.

${ }^{20} \mathrm{Cp}$.: The first world war... ibid.p. 33. Here we can refer to the book of Vilmos HEISZLER- Margit

SZAKÁCS and Károly VÖRÖS: Photo Habsburg, Corvina, Budapest, 1989., which contains interesting further information on family relations , the work of Ferdinand OPLL and Karl RUDOLF - España y Austria, Cátedra, Madrid, 1997. pp. 200-216.-among others about the studies of Alfonz in Vienna.

${ }^{21}$ Z.A. 180. „König Alfons über die Beziehungen zu Frankreich”. Salvador de Madariaga also refers to this political behaviour of Alfonz. See this essay 16.

${ }^{22}$ Ibid. „Der Besuch des Königs von Spanien in Wien”

${ }^{23}$ Salvador de MADARIAGA: Spanien. Deutsche Verlags-Anstalt, Stuttgart-Berlin, 1930. pp.121-126.

${ }^{24}$ Z.A. 180. Blätter aus Ungarn. June 26 1916.. Spanien
} 
As a king of a neutral country Alfonz could and did do humanitarian efforts. This activity of the monarch proved to be so successful that his ruitful efforts were appreciated and thanked at several forums such as the conference of the Red Cross in 1917. His name came up as one of the applicant of the Nopel Prize. ${ }^{25}$

Alfonz created a 'searching and help service' for doing humanitarian efforts. This organisation gave support to the families of missing soldiers. ${ }^{26}$

As proof of the success and acknowledgement of Spanish diplomacy, the embassies and consulates of Spain took over the representation of several countries in the countries at war. Furthermore, there was a point at which the Spanish ambassador to Mardrid protected the interests of narly all the countries.

The international press reported about the efforts of the Spanish King to support the families of missing people. For example the January, 1912, issue of the Current History Magazine, which writes about several concrete cases, in which Alfonz had tried to help some English, Belgian, French and Italian families. They also quote from several letters which arrived at the Palacio Real day by day. Don Emilio Torres, the Marquis of Mendoza, the personal secretery of the King and authorized minister, helped the king in this job. ${ }^{27}$

In several cases the King personally contacted other monarchs to achieve his aims. For example he contacted Frencis Joseph, when he wanted to save the life of a soldier, who was sentenced to death. ${ }^{28}$

The Neue Freie Presse, in its 6th August issue 1915, reports that the search for and identification of 7000 prisonesrs of war had been successful, as a result of the agency directed personally by Alfonz. The writer of the article reports about the everyday tasks and operations of this organisation. According to this, as soon as a request arrives in the palace - there might be several thousands of they daily - the king reports to the POW family that the search for the missing person has started. The task is usually forwarded to the Spanish consul or ambassador of the country where the missing person might be in captivity. The family was informed - usually in a personal letter by the king - of the results. $^{29}$

The people involved either as relatives or friends represented a wide social and national strata.

Some letters were absolutely moving such as the letter of an eight-year-old French girl, who wrote as follows in April 1917: 'Your Majesty! My mother is crying all the time as her brother is in captivity. Yesterday she got a letter and according to it her brother might even starve to death in the camp. Yout Majesty! Could you, please, help him to get to Switzerland, because my mum will become ill soon, I am sure. .. Thank you in advance. Sylviane Sartor, 14 Avenue d'Antin, Paris: I am 8 years old."

The king answered personally. 'Dear Miss! Iwill do my best so taht your mother do not have to cry. But please send me some more information about your uncle so that I can get news about his health and, if possible, I can get him taken to Switzerlan. Best wishes, Alfonz (20 April, 1917)' ${ }^{30}$

The Korrespondenz-Bureau on 17 September, 1915, reports about the case of Austrian and Hungarian citizens, who also asked the Spanish king for help in finding their relatives in Russian and Serbian captivity. However, the search for them was not successful. ${ }^{31}$

He also tried to intervene in the interest of sentenced Russian citizens at the beginning of 1916, when he asked Fürstenberg to apply for a reprieve in their names at His Majesty, the Emperor. ${ }^{32}$

Prince Fürstenberg, on 11 March, 1916, sent a telegram about the humanitarian deeds of Marie Chritine. According to this, the Queen Mother learned that the Austrian Catholic priest and professor,

\footnotetext{
${ }^{25}$ Cp: The first world.... ibid.p. 11. Z.A. 180. 15 June 1916. The announcement of Neues Wiener Tagblatt according to the news of Frankfurter Zeitung.

${ }^{26}$ Cp.: PETRIE: ibid. p. 126. SENCOURT: ibid..p. 153, MADARIAGA: ibid. p. 277.

${ }^{27}$ Current History Magazine, New York, January, 1917. pp, 686-689. and Z.A. 180, 17 August 1915. The article of Epoca on July 29 about the King's intervention in getting permission for letterwriting between POWs and their family members.

${ }^{28}$ Cp: SENCOURT: ibid. p. 153.

${ }^{29}$ Z.A. 180. „König Alfons von Spanien und die Kriegsgefangenen”

${ }^{30} \mathrm{Cp}$ : Petrie: ibid. pp.126-127.

${ }^{31}$ Z.A. 180. „Zwecklose Erkundigungen in Madrid nach Kriegsgefangenen”

${ }^{32}$ HHStA Administrative Registratur, F7 54, Staaten S 1880-1918.
} 
Karl Drexel was taken into Russian captivity in autumn 1914. He was, then, taken to Irkutsk in August 1915, and charged with being a spy. He was sentenced to death. The Queen Mother turned directly to the Czar, Nicholas I threough the Russian Embassy in Madrid so that the priest could be given mercy. As a result of the intervention the Austrian priest and scienticst got not only mercy, but he was also released. ${ }^{33}$

In April 1916, Alfonz submitted a suggestion that the fighting countries should examine possibility of an agreement according to which military emergency units, as well as the representaives of the Red Cross, could collect injured people on battlefields. The head of each states answered that they would take the suggestion into consideration. ${ }^{34}$

A similar initiation of King Alfonz was that injured soldiers should not be left behind frontlines. ${ }^{35}$

According to Hungarian press information, namely the EST, in May 1917, the Spanish King came up with the suggestion of exchanging soldiers in captivity since $1914 .{ }^{36}$

At the same time Alfonz turned to in a very important case: Count Czernin, the Foreign Minister of the K.u.k. Monarchy ordered Fürstenberg in a letter dated May 16 to discuss the following problems with the Spanish king: After Russia, in the February Revolution, dethroned the czar, it is quite likely that the Greek King, Constantin, will have to face a very similar situation. According to the 'solidarity of crowns' the Greek throne should be saved. To achieve this, Alfonz could turn to the British ruler, George V. ${ }^{37}$

Fürstenberg gave a report on the results of talks on 22 May: „The king seemed immediately ready to make the necessary steps. I, however, emphasized that the plan can be successful only if its origin never comes to light". 38

Evidence whether this letter was written by Alphonse to the British emperor cannot be found in HHsSA files. What is certain is that even if he did so it was in vain because the Greek king was forced to resign on 11 June and emigrated to Switzerland. ${ }^{39}$

The list could be continued; however, here- as a conclusion- I want to refer to a collection of HHStA Politisches Archiv of which tells a lot: „The pope's and the Spanish king's intercession for those condemned to death in Banjaluka". Its content - at least regarding files with reference to Spainis not very thorough making precise reconstruction of events impossible. ${ }^{40}$

What is clear: as a result of joint intercession on the behalf of 16 Serbian prisoners -who were accused of spying by Austria and sentenced to death in spring 1916, in Banjaluka- were commuted. ${ }^{41}$

The co-operation between the Pope and King Alphonz was reported by the Zeit on 26 September, 1917, according to which the leader of the Catholic Church suggests the Spanish king be the conciliator in conflicts between powers at war. Spanish newspapers hoped the King will refuse the proposal. $^{42}$

\footnotetext{
${ }^{33}$ HHStA P.A. XX 66 Berichte Spanien 1916. No. 122.

${ }^{34}$ Z.A. 180. According to the Korrespondenz-Bureau report referring to the Temps. 15th April, 1916.

${ }^{35}$ Ibid. Neues Wiener Tagblatt. 3rd May 1916. Der König von Spanien für die Verwundeten.

Prince Fürstenberg refers to this in his report of 7 March 1916. ' Mr. Torres, the personal secretary of His Majesty, paid a visit at my place the other day. He handed over a copy of an instruction of his from King Alfonz, which he had sent to His Majesty, the Austrian Emperor on 4th March. The document contains the suggestion for agreement between the fighting forces, by King Alfonz, to help the injured behind frontlines. Mr. Torres at the same time told me that, although he is not fully convinced that his initiation will meet pozitive agreement, he turned to the fighting countries as several people, among them the Belgian Queen, turned to him to do so...”. HHStA P. A. XX 66 Berichte Spanien 1916. No. 120.

${ }^{36}$ Z.A. 180. 15. May 1917.. Blätter aus Ungarn. „Der König von Spanien für den Austausch der im Jahre 1914 in Gefangenschaft geratenen Soldaten"

${ }^{37}$ HHStA P. A. XX 67 Berichte Spanien 1917. No. 352.

${ }^{38}$ Ibid. No. 334.

${ }^{39}$ cp: Justi.c..p. 65.

${ }^{40}$ HHStA P. A. I 814. Intervention des Papstes und des Königs von Spanien zu Gunsten der in Banjaluka verurteilten Hochverrätter.

${ }^{41}$ ib.report on 29 March, 1917. cp.: Harald JUST: Neutralität im ersten Weltkrieg. Spanien, Schweden und Holland. phil. Diss., Wien, 1966. p. 64., and Friedrich ENGEL-JÁNOSI: Österreich und der Vatikan 1846-1918. Graz, 1960. Bd. 2. p. 283.

${ }^{42}$ Z.A. 180. „König Alfons als Schiedsrichter. Ein angeblicher Plan des Papstes”
} 
Alphonz was appreciated because of his efforts all over Europe, and they were remembered even after the war; French newspapers at the end of October, 1919 -in connection with Alphonz's visit to Paris- talk about the gratefulness of France to the Spanish King for what he did for the benefit of French prisoners of war during the war. ${ }^{43}$

According to Sencourt's estimation, about 700, 000 civilians and 21, 000 soldiers could be repatriated as a result of the activities of the organization established and run by Alphonz; he interceded for 122, 000 French and Belgian, 8, 000 British and 6, 000 Italian war prisoners and in 4, 000 cases he initiated a review in prisoner of war camps. ${ }^{44}$

Aforehand we mentioned how the Spanish diplomacy participated in these tasks; to finish this topic let three representative examples be cited here to prove all these things. On 3 September, 1914, the Neue Freie Presse reports the actions of Don Antonio de Castro y Casaléiz for the sake of Russian and Belgian citizens in the territory of the Austro-Hungarian Monarchy. The ambassador asked the following announcement to be published: „The Spanish embassy in Vienna asks Russian citizens living in the Austro-Hungarian Monarchy to inform the embassy about their residence so that it can inform family members of the concerned".

The author of the article even adds that according to this information the Spanish ambassador took over the protection of Belgian citizens in the Austro-Hungarian Monarchy. ${ }^{45}$

The Fremdenblatt in its issue on 4 October, 1918, commemorates Casaléiz - in connection with his death -in a short article from which we get to know that he had been sent to Vienna in March, 1914, and during the war he was to protect the interests of the Austro-Hungarian Monarchy in enemy countries. ${ }^{46}$

Casaléiz, during his delegation in Vienna, visited ${ }^{47}$ prisoners of war camps in the monarchy several times -including Hungary. Das Neue Pester Journal reports his visit on 29 April, 1918, during which he met Russian, Serbian, English and French interned people and he was quite satisfied with what he saw. ${ }^{48}$

The HHStA Zeitungsarchiv 124 File (Polen-Spanien) contains information about other charities of the Spanish King including Alphonz's participation in an action proposed by the Ministry of Foreign Affairs when the embassy in Madrid started a fund helping Poles suffering war losses. The money was collected by „Pro Polonia”; His Majesty, the Spanish King gave 10, 000 pesetas . ${ }^{49}$

$$
* * *
$$

Here we find it important to discuss the case of ambulance ships, although this topic is strongly related to an independent study analysing the effects of the submarine war in Spain. We, however, decided to take the role of King Alfonz into consideration and deal with it in detail here.

From February 1917, onwards - starting with the declaration of unlimited submarine war by Germay - ambulence ships were often attacked by torpedoes since they sometimes were used to transport weapons and troops as well. ${ }^{50}$

\footnotetext{
${ }^{43}$ Z.A. 180. Französische Blätter. 1919. október 25. „Besuch des Königs von Spanien in Paris”

${ }^{44}$ SENCOURT: ic. p. 153.

${ }^{45}$ Z.A. 71. Spanien 1910-22.

${ }^{46}$ ib. , Der Schutz der russischen und belgischen Untertanen durch den spanischen Botschafter"

${ }^{47}$ Meanwhile Prince Fürstenberg expressed his doubts about the reliability of Casaléiz several times. So he wrote the following on 11 January, 1915: „I want to report briefly that the behaviour of the Spanish ambassador in Vienna seems rather suspicious for me. His attitude and the way he reports war events prove that despite his demonstarted sympathy with us he supports his Fankophil Minister of Foreign Affairs to slander our government and Your Majesty in this court." HHStA P. A. XX 66 Berichte Spanien 1915.

The report of AOK (Armee-Oberkommando) on 24 February, supports it ,... The Spanish embassy in Vienna is supporting entent and unreliable for us.... . However, the military attaché in Vienna is benevolent with us. " HHStA P. A I. 896. Liasse Krieg Spanien 1917. No. 17.297. We got to know similar things about the wife of Casaléiz: „The wife of the Spanish ambassador to Vienna made very unfavourable statements about the Monarchy.”ib.

48 ib. „Unsere Gefangenenlager”. Der Bericht des spanischen Botschafters

${ }^{49}$ Z.A. 124. Report of Korrespondenz-Bureau 17 October, 1915

${ }^{50}$ HHStA P. A. I 1049. Liasse Krieg 61 b-e /61 c/ U-Boot-Krieg. 1 April, 1917. No. 1705.
} 
In April 1917, king Alfonz offered to send Spanish officers to ambulence ships to guarantee that they only carried the wounded. ${ }^{51}$

Prince Hohenlohe, ambassador of the Austro-Hungarian Monarchy to Berlin reported to Vienna that the proposal was supported by the German government as well. ${ }^{52}$

On 22 May, Prince Fürstenberg informs Czernin that he had been granted a private interview with Alfonz where the King said that he had offered the Spanish government's responsibility for the cargo of English and French ambulance ships for the German, French and Brtitsh government.

"England has already agreed, the king is waiting for the reaction of France and Germany."

Alfonz asked Fürstenberg to intercede with His Majesty, the emperor for the support of his proposals in Berlin, too. ${ }^{53}$

On 26 May, Hohenlohe informs Vienna that the German government agrees to let Spanish delegates search the ambulence ships and stay aboard the ship during the voyage as a guarantee. ${ }^{54}$

The idea, of course, could not stop constant abuse of ambulance ships. Several cases were reported by the diplomats of K.u.K. Monarchy. Hohenlohe, as for one, wrote the following on 8 December, 1917: „Three Spanish navy officers, whose duty is controlling English ambulance ships, wanted to return to Spain since English ambulance ships are used not only for their original purpose therefore Spanish officers could not take responsibility for them.". 55

According to another report sent by Dzieduszycki, the military attaché from Madrid in Vienna, ,a reliable confidence of ours informed me about the following: the Spanish military attaché in Paris informed a friend of his in Barcelona in a letter that entent ambulance ships often carried munition and American troops were transported to England on a steam ship of this kind. He admits seeing it with his own eyes. ${ }^{, 56}$

A report from December 1917, says that 25 Spanish navy officers served as controllers on entent military ships in the summer of 1917. The document refers to a crucial detail according to which majority of them accepted this position because of financial reason, so they could have shut their eyes to corruption. Especially ambulance ships transporting troops between Saloniki and Italy can be assumed to have been used fort his purpose. An honest Spanish officer is supposed to ask his resignment because of this reason..$^{57}$

This fact can make the efficiency of Spanish officers' work and the result of this task doubtful misuse of ambulance ships is proved in several cases -, however, participation in several areas of international policy raised the prestige of the Spanish - and mainly that of King Alfonz - during World War I.

The third important reason to determine the Spanish King's policy -as he said to Churchill in the spring of 1914- was related to the economy and trade of Spain.

Since a detailed analysis of Spanish economy during World War I points beyond this study ${ }^{58}$, here I only want to prove the realization of the aim of Alfonz XIII with some data.

Here it is again important to focus on how to evaluate Spain's neutrality declared at the beginning of the war. Spain regarded herself neutral not only in political sense, and tried to take the advantage of her geo-strategical position in economic sense. World War I brought prosperity especially comparing this period to the situation in the $19^{\text {th }}$ century - Spanish economy then was characterised by a special

\footnotetext{
${ }^{51}$ ib. Telegraph of Hohenlohe from Berlin. 22 April, 1917. No. 292.

$52 \mathrm{ib}$.

${ }^{53}$ ib. 22 May, 1917. No. 334.

${ }^{54}$ ib. No. 374.

55 id. No reference

${ }^{56}$ id. Militärattaché Madrid. 31 January, 1918. No. 47.

${ }^{57}$ HHStA P. A. I 896. Liasse Krieg 7a Spanien 1917-18. Nachrichtenabteilung. „Auszug aus den vertraulichen Nachrichten über Spanien bis zum 29. Dez. 1917. Nr. 25.721.

${ }^{58}$ HHStA contains a lot of information about Spanish economy during World War I, here I would like to refer to some fonds of Administrative Registratur: A.R. F17 36: Spanien: Aus-Ein-und Durchlieferungen. Staaten $1880-$ 1918., F23 58: Finanzwesen Spanien, F36 103: Krieg 1914-18. Spanien. Wirtschaftliche Bestimmungen, Massnahmen, F36 242: Wirtschaftsangelegenheiten. Dep. 9 Abt. 50- Spanien
} 
dichotomy: industrialized periphery and rural Hispany ${ }^{59}$ - Spain, however, could not take the advantage of war conjucture in the long run, so the ephemeral ,economic boost" was followed by painful recession accompanied with political consequences which can be foreseen in such a case. The end of the European war pulled down the Spanish economy through ceasing former markets. ${ }^{60}$

During war years entent powers were in a better situation because they could influence Spain not only in politics but in economy as well. The Iberian state needed some foreign help because of the lack of raw materials (e.g. coal, paraffin, cotton) and because of being a transporter of war goods (food, raw materials, military equipment). The sea blocade hindered commerce with Central Powers, so only entent "could help" the country. ${ }^{61}$ Spain lost 65 ships with 140,000 tons $^{62}$ till the end of 1918 because of unlimited submarine war.

Capital income from Spanish trade has increased significantly during the war. In 1914 the country had about 567 million pesetas in gold while in 1918 this sum was 2223 million. ${ }^{63}$ Spain -only talking about weapon transport- sextupled its export from 1914 to $1916 .{ }^{64}$

Stabilization of its financial situation is shown by the favourable rate of exchange of its currency in 1916. In these years about 217 corporations were established with about 220 million - and what is important - not foreign capital. ${ }^{65}$

However, all these changes had their drawbacks. The most tragic of them is the slowly developed lack of food and the high price of food because of the significant amount of exported food generating social unrest which reached its peak point in the spring of 1917.

Many, based on the aforehand mentioned facts, foreshadowed a stable future for the Spanish economy, even after the war years, but this prophecy did not come true.

In order to make the political potrait of Alfonz XIII complete- in the examined period - we have to mention his efforts to achieve peace. ${ }^{66}$

To achieve significant results in peace mediating - it was a role Alfonz really felt ambition for. $\mathrm{He}$ might have well hoped that countries engaged in war take him seriously as Esti Újság in its issue on 29 May, 1916, reports: „"Gaulois” (newspaper) in Paris welcomes the passage of the Spanish King's speech where he emphasises his willingness to act as a peace mediator. Nobody would be as suitable for this role as he is since all war countries accept him". ${ }^{67}$

The king's plan was supported by important Spanish circles and it is proved by an article in the $\mathbf{8}$ órai Újság some days later: „According to information from Madrid the archbishop conference ending the other day in Granada reassured that King Alfonz XIII wants to mediate peace between central and entent powers". 68

In September of this year Alfonz -in a quite pathetic speech at a party in Bilbao- summarized his ideas: „The Spanish flag cannot be seen in battlefields, however, all Spanish people feel how important it is to love and respect this symbol of the country. Therefore I personally dedicate the flag of our nation to serve peace and love. I do so not to be praised but because I stand up for a noble aim as the King of Spain supported by all the Spanish ."69

\footnotetext{
${ }^{59}$ cp: ANDERLE, Ádám: History of S pain. Móra Publisher, Budapest, 1992. pp. 97-108.

${ }^{60} \mathrm{cp}$ : The first ...i.c.. p.7.

${ }^{61}$ ib. p. 8.

${ }^{62}$ cp: MADARIAGA: i.c. p. 274.

${ }^{63}$ ib. p. 275.

${ }^{64}$ cp: Otto QUELLE: Spaniens Wirtschaftsleben und seine Beeinflussung durch den Weltkrieg. Süddeutsche Monatshefte, München, June, 1917, pp. 445-454.

65 ib. p. 452.

${ }^{66}$ We deal with the topic in more details in our study „Spanish peace mediation attempts during World War I” Here we outline the press reaction as a supplement and evidence of the facts in that study.

${ }^{67}$ Z.A. 180. „König Alfons als Friedensvermittler”

${ }^{68}$ ib. Blätter aus Ungarn. 3 June, 1916

${ }^{69}$ ib. Neues Wiener Tagblatt, 8 September, 1916 „Der König von Spanien für den Frieden”.
} 
Reports are continuous in 1917, and this year is outstandingly important regarding peace, since it is full of events influencing the final outcome of the war. ${ }^{70}$

On 26 April Wiener Mittags-Zeitung publishes King Alfonz's statements - rarely declared in such a form - to sign peace treaty in Madrid under his presidency. ${ }^{71}$

Although this ambition of him could not be fulfilled, that does not detract from his merits during the war.

Significant number of historical records and revealed archives emphasize his importance during World War I-even if it is a bit exaggarated- in regaining Spain's former fame.

Salvador de Madariaga goes so far as to compare the international role of Spain in this period to its significance in the $16^{\text {th }}$ and $17^{\text {th }}$ centuries when the countries' marhalls, church leaders and diplomats had a say in European matters. ${ }^{72}$

Alfonz XIII - as we already mentioned - did have a difficult challenge to keep Spain out of military conflict. Ambassador of k.u.k. Monarchy to Madrid, Prince Fürstenberg reports on 6 July, 1914, all those difficulties which limited the Spanish King's actions on the eve of the war.

The ambassador emphasizes the willingness of the young king -whom he found extraordinaly talented- to regain the prestige of his country and his ambition to have an active role in forming international policy. ${ }^{73}$

Due to his talent and suitability to be a monarch he could preserve the stability of this throne which was especially in danger in the spring and summer of $1917 .^{74}$

Reporter of Pester Lloyd in Madrid analysed in a long article in November 1917, the internal crisis in Spain praising the Spanish king in the final part as the best and wisest controller of the foreign policy of the country and whose noblest aim is to maintain peace in Spain. ${ }^{75}$

His diplomatic talent was acknowledged and admired even by his contemporaries. His cousin, princess Pilar wrote about his political talent in this way: „As the greatest living diplomat, the king's personal banters -whatever they are- are hidden. What is obvious as usual is that they are subordinated to Spain's interests. Alfonz is an impulsive, very sensitive ruler who tends to react when his feelings are evoked; so he is a typical Spaniard. He is closely connected to France, but especially to England and Austria. And despite of all these things it is doubted whether Queen Ena or Mary Christine queen mother know who the king favours. ${ }^{, 76}$ What was the reason -among many others- for his success? Salvador de Madariaga answers this question: „The king had unprecendented talent to hide his feelings and the person who could tell even today which side he really took were very wise.,"

\footnotetext{
${ }^{70} \mathrm{cp}$ : Spanish pecae mediating ....i.c. pp.9-27.

71 Z.A. 180. „Die Friedenshoffnungen des Königs von Spanien”

72 cp: MADARIAGA: i. c. P. 277.

${ }^{73}$ HHStA P. A. XX 66 Berichte Spanien 1914. Z 17/P.B

${ }^{74}$ cp: Hans A. SCHMITT: Neutral Europe between War and Revolution 1917-1923. The University Press of

Virginia, Charlottesville, 1988., and P. A. I 896. County Musulin's report from Bern on 17 June, 1917 No. 554.

"According to uncertain sources an anti-dynasty movement is to develop in Spain."

${ }_{75}$ Z.A. 180. Blätter aus Ungarn. 1917. november 29. „Die innenpolitischen Schwierigkeiten in Spanien”

${ }^{76}$ cp: PETRIE: i.c. pp. 121-122.

${ }^{77} \mathrm{ib}$.
} 